\title{
Martin Franc - Věra Dvořáčková a kol., Dějiny Československé akademie věd I (1952-1962)
}

Academia, Praha 2019, 831 s., ISBN 978-80-200-3053-5

První část plánované čtyřdílné souhrnné monografie o dějinách ČSAV v letech 1952 až 1992 je slibným důkazem, že ambiciózní projekt se podaří naplnit hodnotným obsahem, koncepčně výborně propracovaným. Již samotný první díl zachycující první, formativní desetiletí ČSAV (1952-1962) je dílem neobyčejně obsáhlým.

Východiska a cíle jak prvního předkládaného svazku, tak celého plánovaného díla představují autoři v čele s hlavním autorem a redaktorem Martinem Francem v obsáhlé předmluvě. Dějiny ČSAV (všechny svazky) jsou koncipovány jako syntetická monografie, nikoliv jako série dílčích monografií nebo dokonce sborníků prrípadových studií. Představená koncepce je východiskem dlouhodobého promýšlení, postupně spoluutvářeného v diskusích, průběžně publikovaného v teoretických a metodologických článcích a uplatňovaného více či méně již v předchozích projektech a jejich výstupech v podobě dílčích studií nebo šíře zaměřených monografií, které je možné považovat za bezprostředně př́pravné práce pro předkládanou syntézu. Součástí úvodu je vedle metodologických východisek a úskalí také velmi důkladné představení dosavadního výzkumu a pramenné základny.

Metodologické přístupy i představenou strukturu čtyř svazků z hlediska chronologického i tematického autoři v praxi předvedli při zpracování svazku prvního. Z hlediska metodologického dvě poznámky: 1. již z prvního (zde recenzovaného) dílu je patrné, že se autorům podařilo podat kritický, mnohovrstevnatý a plastický obraz stavu bádání o dějinách ČSAV v prvním období její existence, nikoliv jen ,poukázat na své starobylé a úctyhodné kořeny, pokud možno v co nejlákavějším baleni"، (s. 14). 2. V prvním dílu se naopak zatím př́liš neprojevila jejich snaha zapojit do zpracování dějin vedle historiků bez přívlastků a historiků vědy (zpracovávající „,vnější“ dějiny akademie) také odborníky z jednotlivých oborů a ústavů (zpracovávající „své“ obory a instituce); je to však pochopitelné, nebot' příslušné období je již poměrně důkladně probádáno historiky a historiky vědy (ve spolupráci s odborníky na jednotlivé obory), takže větší podíl vědců podávajících pohled na své rozmanité obory ,zevnitř‘ lze očekávat především v budoucích svazcích, analyzujících vývoj disciplín ve stále nedávnější, mnohdy dosud neuzavřené minulosti.

Dějiny ČSAV, vzhledem k jejímu charakteru, zakotvenému mj. v zákonných normách, jsou rovnoměrně prezentovány v obou jejích složkách, tedy jak učené společnosti/sboru akademiků, tak jako komplexu vědeckých ústavů. Akademie jako obří instituce není pochopitelně popisována izolovaně, ale velmi podstatnou součástí monografie jsou kapitoly ukotvující ji v širších kontextech společenských, politických, ideologických i ekonomických, jak v užším československém prostředí, tak v širších mezinárodních souvislostech (komparace je prováděna nejen v rámci sovětského bloku, ale též přes železnou oponu).

Kniha je přehledně členěna do kapitol a podkapitol (orientaci usnadňuje vedle výstižných názvů též desetinné číslování). Po již zmíněné předmluvě následují dvě kapitoly z prehistorie ČSAV před jejím vlastním založením a zprovozněním: 1. kapitola o vývoji mimouniverzitní vědy v Československu před rokem 1945 a diskusích o organizaci mimouniverzitní vědy v letech 1945 až 1952 (M. Franc, M. Kunštát, s využitím textů připravovaných A. Míškovou) a 2. kapitola o vládní komisi pro vybudování ČSAV (A. Jůnová Macková). 
Jádrem první části knihy jsou tři chronologické kapitoly: 3. (1952-1956), 4. (zlomové období 1956/57) a 5. (1958-1962). V jednotlivých podkapitolách (výjimkou je zde kratší, nečleněná 4 . kapitola o zlomovém období) autoři sledují především nejvyšší patra pojednávané problematiky. Zaprvé zde nalezneme velmi důkladné úvodní podkapitoly o politických, společenských a hospodářských poměrech, respektive jejich proměnách (velmi zřetelně zde lze sledovat linku vývoje vědní politiky v návaznosti na politické proměny režimů v sovětském bloku, pochopitelně především v ČSR/ČSSR, ale též v SSSR). Tyto kontextuální kapitoly (autor M. Franc) tvoří konzistentní páteř celého díla. Druhou rovinou chronologických kapitol jsou podkapitoly o základních otázkách vzniku, zprovoznění a fungování ČSAV (legislativa; otázky členství; ř́ídící mechanismy; struktura); vedle hlavního autora se na těchto kapitolách podílela též A. Jůnová Macková. Specifickou složku tvoří obsáhlé podkapitoly s biografiemi vůdčích osobností prvních let ČSAV autorů H. Kábové, J. Šoukala a T. Gecka (velmi důkladné portréty dalších „koryfejů“ ČSAV, především „,nesmiřitelných rivalư“ I. Málka a F. Šorma, jsou obsaženy v jiných podkapitolách); vždy pro př́islušné období vyčleněné podkapitoly o specifickém postavení SAV (autor A. Hudek) a mezinárodní vědecké spolupráci (M. Kunštát s využitím materiálu A. Míškové).

Druhá část monografie (kapitoly 6 až 7) sestupuje na nižší rovinu ve struktuře ČSAV, tedy na úroveň jejích jednotlivých pracovišt' (respektive mezistupňu v podobě sekcí a později vědeckých kolegií), kde autoři věnují pozornost nejenom institucionálnímu členění, ale především - jak nemůže $v$ dějinách vědecké instituce ani jinak být - hodnocení vědecké úrovně a výsledků. V 6. kapitole předchází pohledu na jednotlivá pracovišsté úvodní podkapitola o státním plánu výzkumu (D. Brádlerová, J. Boháček). Analýza vědecké produkce akademie je členěna (nikoliv přesně v souladu s dobovou strukturou) přehledně do tří oblastí: pracoviště věd o neživé přírodě a technických věd, vědy o živé přírodě a chemické vědy a pracoviště humanitních a společenských věd. Vzhledem k tomu, jak vysvětlují autoři v úvodu, že nebylo únosné představit rovnoměrně a do hloubky všechny obory a pracoviště v akademii zastoupené, vydali se jinou cestou. Každá ze tř́ oblastí je uvedena obsáhlou podkapitolou o celé oblasti (zastoupených oborech a ústavech, respektive dalších složkách, počtech zaměstnanců apod., autory jsou M. Josefovičová, M. Franc a V. Sommer), v každé oblasti jsou pak představena dvě (z různých důvodů) stěžejní pracoviště. Pro oblast neživé př́rody je to Ústav teoretické a aplikované mechaniky (V. Dvořáčková) a Ústav jaderné fyziky, respektive výzkumu (E. Těšínská), oblast živé prírody a chemie reprezentuje Chemický ústav (M. Franc) a Biologický ústav (T. Hermann) a pracoviště humanitních a společenských věd zastupuje Filozofický ústav (J. Mervart) a Ústav pro etnografii a folkloristiku (A. Jůnová Macková). Sedmá kapitola pak představuje společná a další pracoviště nebo zařízení akademie: nakladatelství, domy vědeckých pracovníků, základní knihovna, vědecké společnosti při ČSAV (J. Šoukal, T. Gecko, V. Dvořáčková).

Právě $\mathrm{v}$ této části (6. a 7. kapitola) se nejvíce projevila diverzita $\mathrm{v}$ př́stupech a hloubce zpracování dějin jednotlivých ústavů a dalších pracovišt' vycházející nejenom z faktu, že každou zpracovával jiný autor/autorka, ale zejména $z$ faktu, že šlo za prvé o vědecké oblasti diametrálně odlišné, a za druhé, že jednotlivé oblasti jsou v historiografii nestejně předběžně probádané. Na druhou stranu je nutné pochválit, že $v$ mnoha $\mathrm{z}$ těchto kapitol bylo kromě suchého popisu administrativního členění nebo vývoje počtu pracovníků 
a velmi důležitého hodnocení vědecké produkce nebo vědecké komunikace věnováno dost prostoru také každodennosti práce (a nejednou i např́iklad koníčků nebo rekreace) vědců a vědkyň.

Shrnující charakter má 8. kapitola o vztahu ČSAV k dalším institucím vědy v Československu (M. Franc). Ze zásadnějšśch závěrů prezentovaných v této kapitole bych zdůraznil argumentaci autorů, že novější výzkumy nepotvrdily dř́ive často opakovanou zjednodušenou tezi, že založení ČSAV vedlo k dlouhodobému úpadku vědecké úrovně univerzit.

Celkově posouzeno, nejvyrovnaněji působí hlavní linie vyprávění, tedy kontextuální podkapitoly jednoho autora (M. France), velmi dobře na ně navazují základní kameny stavby ČSAV i její historiografické reflexe (kapitoly dalších autorů) v první části. Pro druhou, z pochopitelných důvodů místy trochu disparátní část o vědních oborech a pracovištích jsou velmi cenná nejen úvodní shrnutí vývoje v jednotlivých oblastech, ale základní úroveň působení akademie velmi dobře ilustrují též vhodně vybrané př́padové studie šesti ústavů.

Z hlediska složení autorského kolektivu je důležité, že jsou v něm zastoupeni jak badatelé starších a středních, tak mladších generací, mezi nimiž probíhá zdravé a př́ínosné napětí, projevující se v kombinaci dlouholetých badatelských zkušeností (a výsledků) s inovativními a inspirujícími metodologickými př́istupy. Z formálního hlediska je nutné ocenit převážně velmi živý a čtivý sloh (zejména u M. France). Jazyk kapitol o Slovenské akademii věd působí z hlediska deklarace editorů předložit kompaktní monografii a nikoliv sborník trochu nesystémově, i když na druhou stranu je to možné považovat za zajímavé „retro“ připomenutí $\mathrm{z}$ dějin společného státu $\mathrm{v}$ oblasti vědy (nepochybuji navíc o schopnostech českého čtenáře číst slovensky). $V$ celé práci je patrný vyvážený poměr mezi pasážemi, které byly zpracovány převážně na základě starších výzkumů jiných badatelů, které na základě vlastního dlouhodobého badatelského zaměření autorů a které patří $\mathrm{k}$ nejnovějším výstupům původního badatelského úsilí.

Prameny a literatura jsou uvedeny u každé z kapitol, kniha je vybavena jmenným rejstříkem a anglickým souhrnem. Bohatá a originální obrazová př́loha není jen ilustrativní, ozdobná, ale v mnoha př́padech nese výraznou přidanou informaci. Podobně významnou vypovídací hodnotu mají též př́lohy, zpracované vesměs na základě materiálů předkládaných Prezidiu ČSAV: jmenné seznamy nebo počty členů; přehled organizačního vývoje pracovišst' a jejich umístění; návrhy počtu pracovních sil; počty vědeckých aspirantů 1952-1954; plány investic, rozpočty, mzdové fondy; podané přihlášky vynálezů; přehledy zahraničních styků.

Potvrzuji přesvědčení autorů vyjádřené v předmluvě (s. 14), že jejich snaha o zpracování dějin akademie věd se vydařila a recenzovanou monografii je možné ocenit též ,jako přirozený a doufejme i produktivní př́spěvek historiků $k$ současným úvahám o vhodných modelech organizace a financováni vědy v České republice."

Petr Svobodný

doi: $10.14712 / 23365730.2021 .13$ 